\title{
PROMOTION AS A VARIABLE OF HR MARKETING IN SELECTED CORPORATIONS IN THE CZECH REPUBLIC IN THE CONTEXT OF DIGITIZATION
}

\author{
Jiří Bejtkovskýn \\ ${ }^{1}$ Department of Management and Marketing, Faculty of Management and Economics, Tomas Bata University in \\ Zlín, Mostní 5139, 76001 Zlín, Czech Republic
}

To cite this article: BEJTKOVSKÝ JIŘÍ. 2018. Promotion as a Variable of HR Marketing in Selected Corporations in the Czech Republic in the Context of Digitization. Acta Universitatis Agriculturae et Silviculturae Mendelianae Brunensis, 66(6): 1393-1405.

To link to this article: https://doi.org/10.11118/actaun201866061393

\begin{abstract}
Today's corporations want to differentiate themselves and be more attractive, popular and interesting for their current and potential employees. HR marketing can help corporations gain a competitive advantage and be different. The purpose of this paper was to determine the current state of use of social media platforms based on the biological age of the respondents and the highest level of education achieved of the respondents in selected corporations in the Czech Republic in the context of HR marketing. The primary data was obtained by a self-administered, structured questionnaire targeted at selected Czech corporations and their employees. The total number of respondents was 588 employees. One research question and two research hypotheses have been formulated. The verification or rejection of null research hypotheses was done through the statistical method of the Pearson's Chi-square test. The results came along with finding that there is a statistically significant relation between the active use of social media platforms and the biological age of the respondents and there is a statistically significant relation between the active use of social media platforms and the highest level of education achieved of the respondents in selected corporations in the Czech Republic.
\end{abstract}

Keywords: Czech Republic, digitalization, HR marketing, human resource management, marketing mix, promotion, recruitment, social media platforms

\section{INTRODUCTION}

Laumer, Eckhardt and Weitzel (2010) claim that demographic challenges and the war for talent are seen as the most important trends in corporations of all sizes and in all industries, even ahead of, for example, social media or the global economic crisis.

At present, the impact of technological progress, technology and other external re-sources has occurred and changes take place in personnel activities and processes in terms of human resource management (Galovská, 2017).
Strenitzerová (2016) refers that the labor market is a highly competitive environment. Human resource managers have found out that hiring high quality employees is not as easy as it was in the past. The corporations want to differentiate themselves and be more attractive and interesting for their workforce. HR marketing can help corporations gain a competitive advantage and be different. The employer branding helps corporations to differentiate themselves from other corporations on the market. 
The modern world so increasingly depends on human resources. The concept of marketing, based on long-term relationships with the customer, is gaining momentum and it becomes increasingly important to find, gain highly qualified human resource and subsequently to retain loyal workforce for a long time, which owns information on customers and on the products offered, is trained and is interested in the corporation. This is possible due to the strong employer brand (image, name, brand and so on) of the corporation (Lvovna and Viktorovich, 2017).

Regarding this, Jánošová (2016) says that nowadays, corporations tend to attract employees who not only have the necessary qualifications, skills and knowledge, but also desirable personality characteristics, who are optimally motivated and have the active and energetic attitude to work and are flexible and ready to change.

Berlet (2015) says that the human resources situation is characterized by a qualified manpower shortage.

According to Urbancová and Hudáková (2017), a lack of qualified workforce and constant struggle for talents, along with the retention of most valuable employees, belong to important personnel issues for the majority of corporations (organizations, companies, firms, etc.) nowadays. Concept of HR marketing can very help in these areas. Within human resource marketing human resources officers become those marketers who strive to keep their corporation's name in the minds of all stakeholders, thus drawing their attention to corporation's qualities as an employer, and in such a way winning by taking care of the employees.

Regarding this, Charbonnier-Voirin, Poujol and Vignolles (2017) claim that the war for talent has led corporations to develop a strong employer brand to attract and retain skilled staff.

According to Antošová (2005), the human resource management perspective through human resource marketing has a realistic basis today and in the conditions of companies in the process of transformation, as it leads to a comprehensive and balanced approach to human capital and a combination of objectives in this field, with the broader strategic goals of the corporation in the consistent application of strategic management knowledge.

Regarding this, Chapman and Webster (2003) affirm that advances in technologies and technological development have a profound impact on the business practices of many organizational functions, including financial systems, sales, human resource management, marketing, and production.

For many today's corporations, online recruiting (E-recruiting), digitalization and digital era have been a significant response to their human resource challenge. But E-recruiting is not one specific technique. It includes several different tools and a wide variety of ways to use them. The major techniques include using general commercial sites, specialized job sites, chat rooms or newsgroups, corporation web sites, and social media platforms - for example Facebook, Instagram, LinkedIn, Twitter, YouTube and others. Corporations that use E-recruiting methods will enjoy a competitive advantage over those that fail to do so. This is because E-recruiting is relatively inexpensive, has the ability to reach prospective employees who might not be accessible using costlier, more conventional methods, and can be much faster and more efficient than other methods (Thomas and Ray, 2000).

\section{Human resource marketing (HR marketing)}

The term HR marketing (personnel marketing) began to appear in professional literature in the Czech environment in the mid-1990s. The first records of its use in practice appeared at the turn of the millennium, when HR marketing was being implemented by corporations. At the beginning it was perceived in the majority of transformed economies as a tool for recruiting employees. Today, in the 21st century, in HR marketing this concerns HR activities connected with recruiting and stabilizing workforce by means of market analysis (the offer of working resources and competing job opportunities), the presentation of the corporation on the labor market and the creation of a good employment reputation for the corporation (Ungerman and Myslivcová, 2016; Szozda, 2011).

Regarding this, Jánošová (2016) says that today HR marketing is seen as a process to ensure the corporation (organizations, companies, firms, etc.) of long-term quality workforce and strategic potential. It is working closely with HR management and forms the basis of information. It deals with target groups by different of elements communication in order to increase the attractiveness of the corporation as a potential future employer.

HR marketing represents a relatively new field of HR activities in the corporate and business practice. The essence lies in the fact that the potential employee is becoming the customer/client and management through marketing tools is doing everything possible in order to gain and keep employees in the corporation (Nadányiová, 2016).

Ungerman (2016) perceives HR marketing as a new area which defines employees (current and potential) as customers.

According to Klimentová (2008), HR marketing has emerged as a separate area of human resource activity by being separated from HR management. HR marketing was created at a time when a simple job search advertisement (announcement) was insufficient and because of the predominant supply of jobs (or a lack of adequate employees) on the labor market, it was necessary to apply an active approach to seeking, selection, acquiring, motivating and persuading of the employees to decide for the offered job. 
Instead of products and services market, it is talking about labor market where the demand for labor meets the offer of available positions by corporations. In this case, job applicants are considered to be customers and offer is provided by employers (Gogolová, Poniščiaková and Ivanková, 2015).

A typical marketing mix applied to the human resources management can be established using marketing mix elements of classic marketing. Antošová (2005) introduces a definition of different elements of the marketing mix applied to human resource management: (1) product, (2) price, (3) place, (4) promotion.

Regarding this, Bannikova and Kuchkildina (2013) mention that the aim of HR marketing does not restrict on capability to control the situation on labor market to cover organizational needs efficiently, but to expand different ways of using segmentation, as long as using the method of internal competitiveness among staff.

\section{Product-job, position}

According to Antošová (2005), the product, so a job, introduces a fundamental element of typical the marketing mix applied to the human resources management when a corporation considers hiring new workforce for a newly-created position or considering filling an existing position or a vacant position as a part of internal mobility. A prerequisite for an elaborated job vacancy is a very good description of the vacancy and also the specification of demands to be fulfilled by an applicant that a corporation decides to search for and to hire from the labor market by means of the analysis of available job applications.

\section{Price - motivation and reward for work}

Price, so a motivation and remuneration for work at the position which is offered, is the second tool of a mix of personal marketing. Remuneration (in the form of wage, salary, bonuses or other rewards, or non-financial reward in the form of employee benefits) represents the price of the work opportunity in the same way as it is in the classic marketing mix. It is a product evaluation element. One of key questions of remuneration is an appropriate, equitable and motivation system. Therefore, the remuneration system should be specific to each corporation (organization, company, firm, enterprise) for its needs and for the needs of its employees, albeit depending on the economic situation, the market position and competitive pressure (Antošová, 2005).

\section{Place - corporate culture}

Place, so a corporate culture, understood in terms of place of concrete work performed. A corporate culture creates both the internal and the external framework for the functioning of the HR marketing, employees' behaviour, communication inside the corporation, relations within the corporation, training and development of employees, standards, and training priorities. Although these elements are mostly nontangible, it must be counted and applied to activities of the employees (Antošová, 2005).

\section{Promotion - presentation of the job offer and the corporation}

Antošová (2005) says that the promotion, so a clear presentation of the job offer and the corporation at the labor market, it means unambiguous, obvious and understandable job vacancy offer, able to motivate and get sufficient attention of applicants. The corporation may use different methods when making its bid, the choice of which depends on various factors such as the attractiveness of the profession, the importance of the job in the corporation, the sources of potential candidates. A prerequisite for effective job presentations is the exhaustive information for the potential candidate and the willingness to communicate. Such information may include a job title, a brief description of the job activities, duties and responsibilities required by the post, educational requirements, qualifications, skills, previous experience, as well as the personality requirements of the tenderer. It is also appropriate to include information about specifications of the working conditions and the offered positive facts characteristic of the corporation concerning the quality of working life, the possibilities of education and further development of employees.

Lvovna and Viktorovich (2017) present a marketing mix applied to the human resource management similar to Antošová (2005). The Tab. I presents marketing mix in HR marketing according to Lvovna and Viktorovich (2017).

The Tab. I presents the structure of the marketing mix in HR marketing according to Lvovna and Viktorovich (2017).

HR marketing is a useful tool also to help identify the needs, wishes and desires of current and potential employees. By identifying and meeting

I: The structure of the marketing mix applied to human resource management according to Lvovna and Viktorovich

\begin{tabular}{cccc}
\hline Product & a vacant post & Product & a human work \\
Price & time, education, qualification & Price & payment \\
Place & a working place & Place & a working place \\
Promotion & an announcement of hiring (motivation & Promotion & a work application \\
\hline
\end{tabular}

Source: Lvovna and Viktorovich (2017) 
employee's needs, it can reveal competitive advantages to other corporations and thus ensure competitive advantage (Nadányiová, 2016; Antošová, 2005).

\section{Digitalization and digital era}

Bengtsson and Bloom (2017) present the thesis that new technologies and overall the technological development enables new forms of corporations, since it allows new ways of interaction, relations and efficient and faster communication.

Bredin and Söderlund (2011) discuss the emergence of project-based corporations as a result of the online environment and technological development. They also talk about approaches on how to flexibly meet the technological development.

A turbulent environment, global competition and digital era require that corporation will be adaptable, flexible and ready for opportunities and changes. The development of science in the broadest sense and the creation of the information society are considered the main factors of today's world (Jánošová, 2016).

The rapidly increasing technological development and its ever-increasing proliferation results in digitalization of the society. This digital revolution has consequences for contemporary corporations multiple levels. Digitalization has an influence on customer preferences, buying behavior, marketing, management and business performance. The digital era demands HRM to evolve, as it requires new HR competencies, new employment forms and quick HR processes (Bengtsson and Bloom, 2017).

Regarding this, Nadányiová (2016) mentions that however, the digitalization and globalization of markets causes, that also the field of HR marketing must adapt to changing conditions and current trends, challenges and opportunities which include modern technologies and so on.

According to Bondarouk and Ruël (2009), digital technology modifies every corporation. The process of digitalization is changing how corporations communicate, plan, recruit, manage, stimulate, remunerate, support and educate workforce as well as other HR activities and processes. It can be talked about digital HRM or e-HRM.

Regarding this, Watson (2009) argues that a key part of the core mission of human resource department is to attract, support and develop the employees in line with the overall organizational strategy. This idea highlights the importance and necessity of HR marketing and its individual variables.

\section{Electronic Human Resource Management (E-HRM) and social media platforms and mobile devices}

A large amount of people is active on social media platforms. Social media can be characterized as digital platforms on which users can create a profile, connect with other users, generate and distribute content and engage in interactive communication. Nowadays, there are many different social media platforms and since these differ with regard to the specific communication characteristics, this might translate into different user reactions. Social media represent a remarkable context and differ significantly from more traditional communication sources, which might influence cognition and effect of its users (McFarland and Ployhart, 2015).

Regarding this, Nikolaou (2014) concluded from the evidence that social media seem to be an ideal new tool for attracting both active and passive job seekers, but scientific research is lagging far behind (Roth, et al., 2016; McFarland and Ployhart, 2015).

According to Dineen and Allen (2013), the boom of the Internet changed the recruitment process and it has increased the opportunities for interactive communication. The current and potential employees so can interact with the corporation by communicating through private messages, share their work experiences, liking a post or by writing a reaction on a post of the corporation et cetera.

Regarding this, Carpentier, Van Hoye, Stockman, Schollaert, Van Theemsche and Jacobs (2017); Dabirian, Kietzmann and Diba (2017); Ventura (2013) publish that for example, the very popular social media platforms are: (1) LinkedIn, (2) Facebook, (3) YouTube, (4) Twitter and (5) Instagram.

\section{MATERIALS AND METHODS}

The contribution focuses on the promotion as a variable of HR marketing in selected corporations in the Czech Republic in the context of digitization and social media platforms.

The goal of this submitted paper was to determine the current state of the use of social media platforms based on the biological age of the respondents and the highest level of education achieved of the respondents in selected corporations in the Czech Republic in the context of HR marketing.

Professional scientific monographs, scientific journals and scientific papers in the Scopus database and Web of Science database dealing with the current issues, namely HR marketing, digitalization and social media platforms, were analyzed within the secondary sources.

Primary data were obtained by qualitative and quantitative marketing research. Some of the results are presented in this paper. Two research hypotheses $(\mathrm{H} 1, \mathrm{H} 2)$ and one research question (RQ1) were formulated on the basis of exploratory research, especially literary research, analysis and evaluation of the information and facts obtained:

- Hl: There is a statistically significant relation between the active use of social media platforms and the biological age of the respondents.

- H2: There is a statistically significant relation between the active use of social media platforms and the highest level of education achieved of the respondents. 
- RQ1: What kind of source of information about a job vacancy in selected corporations in the Czech Republic was the most frequent according to addressed employees?

The qualitative marketing research was conducted through semi-standardized interviews with HR managers of selected corporations in the Czech Republic in 2017 (in February). This exploratory research served to clarify the research goal and to prepare an anonymous questionnaire survey.

The questionnaire survey was realized as a form of the quantitative marketing research. The structured questionnaires were available in the electronic as well as printed form and distributed among employees of selected corporations in the Czech Republic.

Closed, semi-open and open questions, which were compiled on the basis of the study of professional scientific monographs, documents and semi-standardized interviews, were used to obtain answers.

Respondents were employees of selected corporations in the Czech Republic who worked in the selected corporation from zero to six months. So it was the newly recruited employees.

The corporations were selected only for the given research and their composition is random, it does not respect the exact division ratio in the national economy. The questionnaire respected the ethical aspect and anonymity of respondents.

In March 2017, a pretest of the structured questionnaire was also performed. The pretest of the structured questionnaire was carried out on a sample of eighteen respondents. A main research was conducted on the basis of an evaluation of the results. This research was carried out from April to December 2017.

A final range of the sampling frame, which served for objectives of mathematical statistics-related evaluation of research hypotheses, comprised five hundred and eighty eight filled-in structured questionnaires from employees of selected corporations in the Czech Republic.

In order to evaluate the research results, descriptive statistics tools such as absolute and relative frequencies were used.

The verification of the proposed research hypotheses was performed by the Pearson's statistical method of Chi-square test. Chi-square test is based on the dependence measurement. This is the test that detects whether there is the dependence between statistical characters. That means that the occurrence of certain character values A can assume probability of occurrence of a certain character values B. If the P-value is lower than the chosen significance level (typically $5 \%$, i.e. 0.05 ), the zero hypothesis is rejected-the difference between the abnormalities found in the sample and the expected abundances is too large to be the result of random selection, i.e. it is statistically significant.

To evaluate the data, a statistical software IBM SPSS Statistics 23 and Microsoft Excel 2013 were used.
The results of quantitative marketing research were used for answering the formulated research question.

The selected scientific methods, including analysis, synthesis, induction and deduction, were used for processing of both secondary and primary information resources and to define the research conclusions.

\section{Characteristics of respondents sample and corporations sample}

The quantitative marketing research, an anonymous questionnaire survey, was comprised of 588 respondents - employees of selected corporations in the Czech Republic.

The respondents were segmented according to the following criteria: (1) gender of respondents, (2) biological age of the respondents, (3) the highest level of education achieved of the respondents and (4) the length of current employment of the respondents in selected corporations in the Czech Republic.

The selected corporations in the Czech Republic were classified according to the following characteristics: (1) industry classification and (2) corporation category. The overall number of selected corporations was 426.

The overall number of respondents and the overall number of selected corporations are different because there were more newly recruited employees in some corporations.

The structure of the addressed employees working in selected corporations in the Czech Republic is shown in the Tab. II below.

The Tab. IIdescribes the structure of the addressed employees working in the selected corporations in the Czech Republic. The variables are: (1) gender, (2) biological age, (3) highest level of education achieved and (4) length of current employment of the respondents working in selected corporations in the Czech Republic.

The structure of the selected corporations in the Czech Republic is shown in the following Tab. III.

The Tab. III presents the structure of the selected corporations in the Czech Republic.

\section{Sampling}

The population of this research is 10,555,945, which is the total population of the Czech Republic in the year 2018 (in February). For determining the sample size, the Yamane formula has been adopted:

$n=\frac{N}{1+N \times e^{2}}$

Where, $\mathrm{n}=$ required size of sample; $\mathrm{N}=$ population size; and $\mathrm{e}=$ margin of error. Therefore the required sample size for this study is:

$n=\frac{10555945}{1+10555945 \times 0.05^{2}}$ 
$n=399.98 \approx 400$

With $\mathrm{N}=10,555,945$ and $\mathrm{e}=5 \%$ (95\% confidence level), the required sample size is 400 respondents. Overall 588 questionnaires were used for further analysis.

\section{RESULTS}

This chapter describes the main results of research realized in selected corporations in the Czech Republic.

Four hundred and twenty-six corporations participated in the research. The total number of respondents was five hundred and eighty-eight. Respondents were employees of selected corporations in the Czech Republic who worked in the selected corporation from zero to six months. So it was the newly recruited employees.

The overall number of selected corporations and the overall number of respondents are different because there were more newly recruited employees in some corporations.

The active use of social media platforms was specified by the offer in the questionnaire by a daily or weekly frequency. The options were: (1) every day, (2) twice - four times a week, (3) five times - six times

II: The structure of the addressed employees working in selected corporations in the Czech Republic

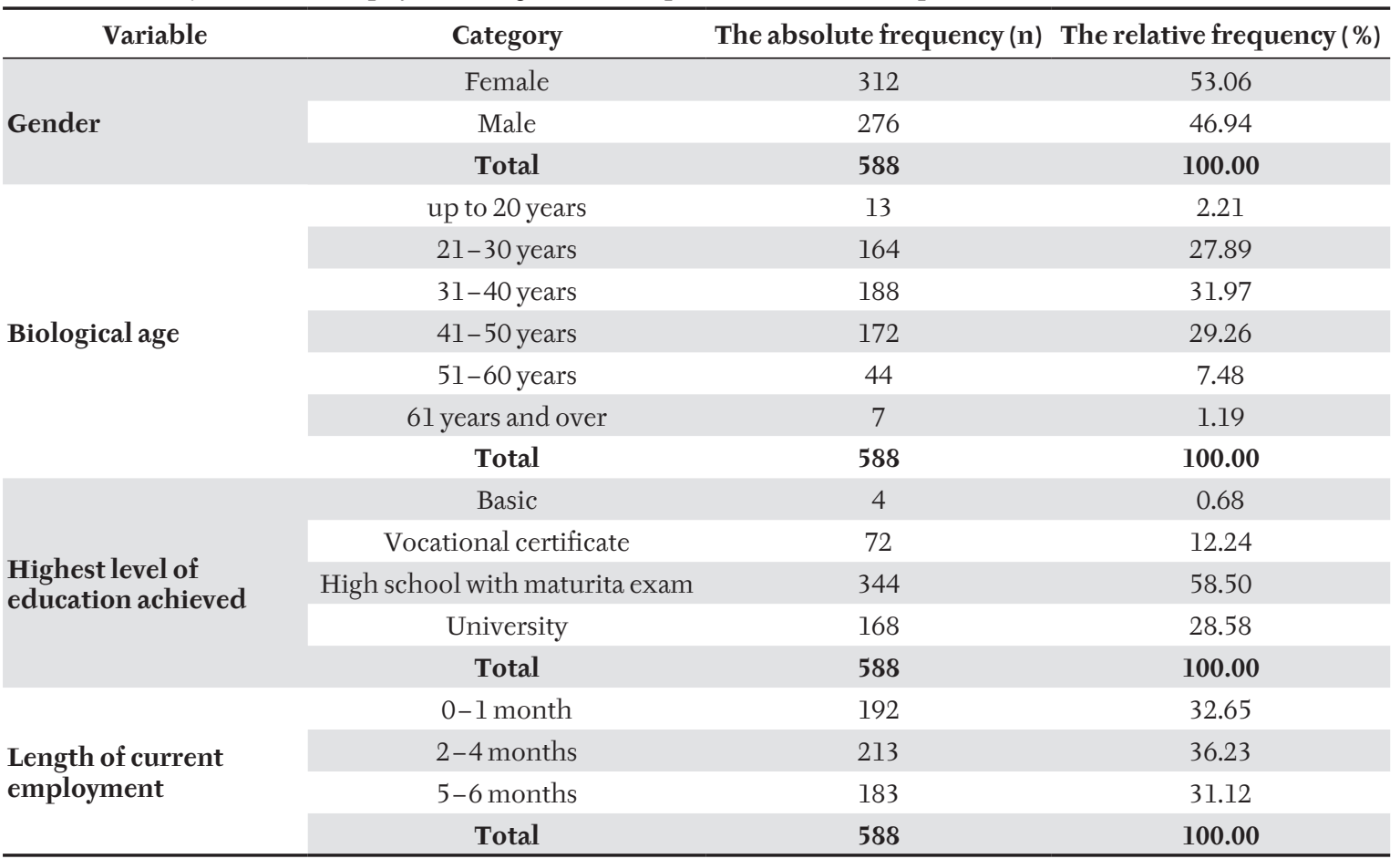

Source: Authors, own survey

III: The structure of the selected corporations in the Czech Republic

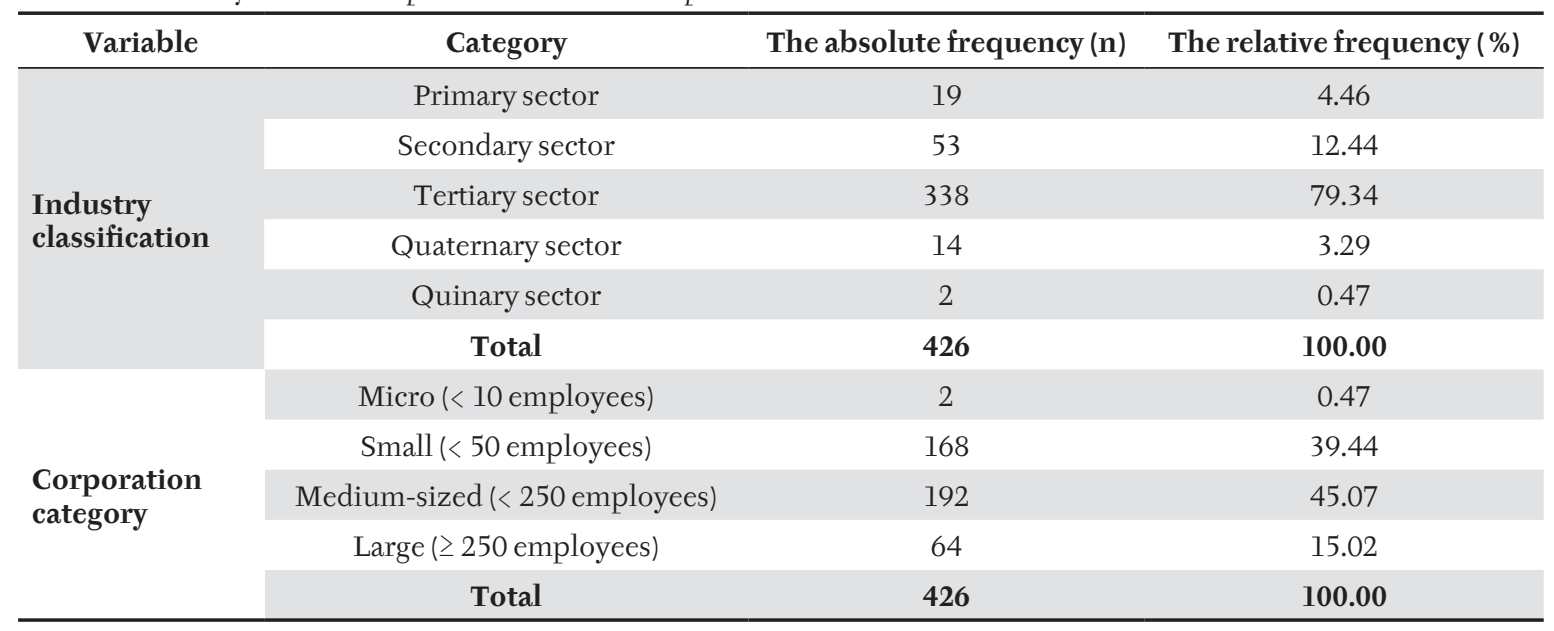

Source: Authors, own survey 
a week, (4) once times per week and (5) I do not use social media platforms.

Two research hypotheses $(\mathrm{H} 1, \mathrm{H} 2)$ and one research question (RQ1) were formulated on the basis of exploratory research, especially literary research, analysis and evaluation of the information and facts obtained:

- Hl: There is a statistically significant relation between the active use of social media platforms and the biological age of the respondents.

- H2: There is a statistically significant relation between the active use of social media platforms and the highest level of education achieved of the respondents.

- RQ1: What kind of source of information about a job vacancy in selected corporations in the Czech Republic was the most frequent according to addressed employees?

A questionnaire survey was the primary source of information about carried research. The hypotheses were verified individually for each criterion using the statistical method of the Pearson's Chi-square test of independence on the research hypotheses. To evaluate the data, a statistical software IBM SPSS Statistics 23 and Microsoft Excel 2013 were used.

The research hypothesis 1 (H1): There is a statistically significant relation between the active use of social media platforms and the biological age of the respondents.

- H0: There is no correlation between the active use of social media platforms and the biological age of the respondents.

- HA: There is correlation between the active use of social media platforms and the biological age of the respondents.

The data that characterize the research hypothesis 1 (HI) are shown in the Tab. IV.

When considering a dependence of the relation between the active use of social media platforms and the biological age of the respondents in the selected corporations in the Czech Republic, the p-value of Pearson's Chi-square test of independence is lower than the defined level of significance (0.05). Because of the low numbers in the table, some categories have been merged; five cells have expected count less than five, the minimum expected count is 1.21. The result of a verification of the research hypothesis $\mathrm{Hl}$ introduces finding that the null hypothesis (HO) of independence was therefore rejected at a level of independence of $5 \%$. The $\mathrm{Hl}$ hypothesis was therefore not rejected.

The Hl hypothesis-there is a statistically significant relation between the active use of social media platforms and the biological age of the respondents-was therefore confirmed. It can be stated, therefore, that lower age respondents showed more active use of social media platforms than older respondents according to biological age. According to Cramer's V, it can be concluded that a relation is considered as weak (small).

The research hypothesis 2 (H2): There is a statistically significant relation between the active use of social media platforms and the highest level of education achieved of the respondents.

- H0: There is no correlation between the active use of social media platforms and the highest level of education achieved of the respondents.

- HA: There is correlation between the active use of social media platforms and the highest level of education achieved of the respondents.

The Tab. VI shows data that characterize the research hypothesis 2 (H2).

The result of verification of the research hypothesis H2 shows that the p-value of Pearson's Chi-square test of independence is 0.087 . The result of its validity verification indicates that the $p$-value of the Pearson 's Chi-square test of independence is lower than the specified limit value of 0.1. Thus, the H0 hypothesis is rejected on the significance level of $10 \%$.

In this case, it can be concluded that there is a statistically significant relation between the active use of social media platforms and the highest level of education achieved of the respondents. It can be said that respondents with a higher level of education (high school with maturita exam and

IV: The verification of the research hypothesis Hl by means of the Pearson's Chi-square test

\begin{tabular}{ccccc}
\multicolumn{4}{c}{$\begin{array}{c}\text { H1: There is a statistically significant relation between the active use } \\
\text { of social media platforms and the biological age of the respondents. }\end{array}$} \\
\hline The statistical method & Chi-square & df & p-value & .000 \\
\hline Pearson's Chi-square test & 80.189 & 12 & weak/small \\
\hline Cramer's V & .213 & Statistical Interpretation & .
\end{tabular}

Source: Authors, own survey, own processing at SPSS Statistics program 23 (2018)

V: The verification of the research hypothesis $H 2$ by means of the Pearson's Chi-square test

H2: There is a statistically significant relation between the active use of social media platforms and the highest level of education achieved of the respondents.

\begin{tabular}{cccc}
\hline The statistical method & Chi-square & df & p-value \\
\hline Pearson's Chi-square test & 13.820 & 8 & .087 \\
Cramer's V & .108 & Statistical Interpretation & weak/small \\
\hline
\end{tabular}

Source: Authors, own survey, own processing at SPSS Statistics program 23 (2018) 
university) use social media platforms more actively than respondents with basic education (basic and vocational certificate). According to Cramer's V, it can be concluded that a relation is considered as weak (small).

The research question 1 (RQ1): What kind of source of information about a job vacancy in selected corporations in the Czech Republic was the most frequent according to addressed employees?

The structured questionnaire, besides other things, also included a selection question. This selection question examined the sources of information from which the respondent learned about a job vacancy in a selected corporation. The respondent had a choice of the following alternatives: (1) a corporate website, (2) an open day in a selected corporation, (3) prints (newspapers, magazines and so on), (4) a radio, (5) an advertising in urban public transport, (6) Internet job portals (for example jobs. cz, prace.cz, portal.mpsv.cz/sz/obcane/vmjedno, profesia.cz and so on) and/or email messages, (7) a leaflet, (8) a conference, (9) a job fair, (10) an Employment Department, (11) a personnel agency, (12) a headhunting agency, (13) a recommendation from a friend or mate, (14) a recommendation from colleagues, acquaintances and (15) social media platforms (for example LinkedIn, Facebook, Instagram, YouTube, Twitter and so on).

The Tab. VI presents the sources of information about a job vacancy according to addressed employees and their answers.

As it can be seen from the Tab. VI above, the most used source of information about job vacancy was Internet (Internet job portals), according to addressed employees.

Personnel agencies were on the second place and recommendations from a friend or mate was on the third place. Social media platforms finished on the fourth place. The other used sources of information about job vacancy according to the frequency of respondents' answers are shown in the Tab. VI.

In connection with the evolution of digitization and online environment, it is obvious that human resource management is not lagging behind in progress, development, technologies and innovation. A large number of people are active on the Internet and on social media platforms. Therefore, it is no wonder that the most represented option related to the source of information about a job vacancy in selected companies in the Czech Republic was the Internet (Internet job portals).

\section{DISCUSSION}

According to Vannan and Chandra Mohan (2014), the human resource management function in corporations needs to play an increasingly strategic role in the current knowledge economy, online environment and digital era as the human capital is the most important asset for corporations.

Regarding this, Stone and Deadrick (2015) say that today, the field of human resource management is experiencing numerous pressures for change. Shifts in the economy, globalization, domestic diversity, online world, technology, and digitalization have created new demands for corporations, and propelled the field in some completely new directions. These challenges also create numerous opportunities for human resource and corporations as a whole.

In the current climate, which is characteristic in its rapid pace of development and the need for high flexibility, human resource management becomes the subject of many changes (Cocul'ová, 2015).

VI: The sources of information about a job vacancy according to addressed employees and their answers

\begin{tabular}{lcc}
\hline \multicolumn{1}{c}{ The sources of information about a job vacancy } & The absolute frequency (n) & The relative frequency (\%) \\
\hline Internet job portals (and/or email messages) & 268 & 45.58 \\
Personnel agency & 64 & 10.88 \\
Recommendation from friend or mate & 53 & 9.01 \\
Social media platforms & 44 & 7.48 \\
Recommendation from colleagues, acquaintances & 42 & 7.14 \\
Employment Department & 41 & 6.97 \\
Prints (newspapers, magazines) & 17 & 2.89 \\
Advertising in urban public transport & 13 & 2.21 \\
Radio & 12 & 2.04 \\
Corporate website & 11 & 1.87 \\
Job fair & 9 & 1.55 \\
Conference & 5 & 0.85 \\
Open day in a selected corporation & 4 & 0.68 \\
Leaflet & 3 & 0.51 \\
Headhunting agency & 2 & 0.34 \\
Total & 588 & 100.00 \\
\hline
\end{tabular}

Source: Authors, own survey 
Nowadays, Internet usage is ubiquitous and the primary source of information for many people. This might also be one reason why the Internet has also established as the media of choice for HR marketing and recruiting process. However, with the growing popularity and use of mobile Internet, HR managers are facing new challenges in their human resource recruitment activities (Böhm and Niklas, 2012).

Human resource marketing is a fairly young science discipline. In essence, it means the application of marketing tools and principles in the field of human resource management, from the time of recruitment process to redundancy process of employees.

In addition to the job search services, the online environment and digitalization era have also provided corporations with an excellent means of communicating recruitment messages to both the active and passive job searchers (Brice and Waung, 2002).

Regarding this, Stone and Dulebohn (2013) claim that technology has a dramatic impact on human resource management processes and practices. For example, technology, especially the World Wide Web, has helped modify many HR processes including human resource planning, recruitment, selection, performance management, work flow, and compensation.

Plummer, Hiltz and Plotnick (2011) claim that corporate website, social media platforms, which were once thought to be an Internet fad, are dramatically changing the ways in which employers, recruiters and jobseekers connect and interact. Social media platforms and other digital tools are becoming ever more appealing to recruiters because they do not only have a large pool of members, but also, these members are increasingly using them for job searching and professional community and networking.

Regarding this, Chapman and Webster (2003) concluded, according to their research findings, that the use of HR technologies is in a state of flux with most corporations continuing to use a mix of traditional and technology-based human resource methods. Furthermore, technology-based solutions are not necessarily a panacea for human resource managers. Nearly third HR managers reported that their attempts to use human resource technology have resulted in limited or moderate success.

Research surveys of Laumer, Eckhardt and Weitzel (2010) reveal that human resource management most pressing challenges are staff retention and internal and external employer branding. Overall, the results emphasize the importance for an E-HRM that needs to be both effective, adequately fill vacancies, and efficient, make best use of human resource.

According to Maurer and Liu (2007) and their discoveries in context digitalization era: (1) the recruitment is, in reality, job marketing; thus, the design focus should constantly be on creating a virtual recruiting environment that meets the needs of potential employees, (2) it is important to define the target market of desired job applicants and understand their internal motivation and job product knowledge characteristics, (3) to reach job seekers with different levels of experience or interest in seeking a job, E-recruiting or social media platforms must provide carefully targeted levels of information richness, interactivity, and aesthetic appeal.

Regarding this, Sheng, Fui-Hoon Nah and Siau (2005) suggest strategic implications of online and mobile technology in digital era in human resource management field: (1) improve working process, and (2) increase effectiveness internal communication and knowledge sharing.

Arjomandy (2016) says that social media has dramatically changed how we communicate both in life and in business. Based on his research, he suggested four characteristics of social media platforms and their implementation in E-HRM area: (1) open, (2) internal, (3) specialized, (4) and segmented.

Research results based on data from 814 respondents searching actual corporate website show that job information (directly) and corporation information (indirectly) are related to intentions to pursue employment when a priori perceptions of image are controlled (Allen, Mahto and Otondo, 2007).

Egerová and Eger (2017) declare in their studies that in recent years, the use of corporate websites to recruit potential job applicants has been playing an important role in HR practices. It is also evident that corporate websites are considered as one of the key tools for attracting and selecting millennial generation. Furthermore, their research accesses differences between SMEs and large enterprises in using corporate websites as an important tool of external HR marketing. On the one hand, the findings of the study show that most corporations provide explicit organisational related information and available information regarding job characteristics. On the other hand, the findings indicate that most corporations do not communicate components regarding their culture and do not provide content specifically targeting college or university candidates. Moreover, only half of the corporations from their sample use social media platforms as a part of their recruitment efforts.

Regarding this, Urbancová, Stachová and Stacho (2015) publish research results and they say that employers in the Czech Republic most frequently present themselves to potential candidates via their corporations' websites (43.7\%), positive references (38.7\%) and media advertisements (32.4\%). A similar ranking obtains for Slovakia. Corporation websites are used $47.5 \%$ of the time, positive references $42.5 \%$ of the time and media advertisements $33.2 \%$ of the time. In both countries, employees are 
hired for managerial positions primarily using the corporation's own resources, promoting the building of the employer's brand.

Ryan and Wessel (2015) present, on the basis of their research, these findings related to new technologies, the online world and the digital era: (1) greater expectations of receiving information and receiving it quicker, (2) differences in employer and employee expectations of personal use of organizational technology, (3) clashes from tracking non-job related information and expectations of privacy, (4) greater expectations of control over decision-making.

In connection with online environment and digitization, different aspects of the use of new technology are noted including computer-based testing, Internet-based recruitment and candidate assessment, telephone-based and video-based interviews, video-based situational judgment tests, and virtual reality scenarios (Anderson, 2003).

Melanthiou, Pavlou and Constantinou (2015) introduce findings from their research that the online recruitment method has a lot of benefits but also pitfalls of which recruiters should be aware. Furthermore, it seems that the contemporary practice of employee screening through social media platforms can highly affect the hiring decision and legal implications are likely to arise with the wrong use of information. On the contrary, a well-designed system and strategic utilization of available information about potential candidates may significantly assist the recruitment of employees with the most suitable skills and competencies. Furthermore, the survey showed that from the 117 participating corporations, 86 (73.5\%) maintain social media platforms accounts with the most popular answers being Facebook with $65.0 \%$, LinkedIn with $40.2 \%$, and Twitter with $20.1 \%$. A number of corporations (10.3\%) reported their involvement in other social media platforms like Instagram, Pinterest, and Google +.

The research results of Moqbel and Fui-Hoon Nah (2017) suggest that corporate social media use can increase workplace integration, which further enhances performance directly and indirectly through positive emotions. Corporate social media use also has a direct relationship with performance.

Nikolaou (2014) explored how social media platforms are used during job search activities and how recruiters use them in the attraction recruitment and screening process. His results showed that job seekers still seem to use job boards more extensively than social media platforms. It is interesting to note that the association between LinkedIn usage and its effectiveness, on the one hand, and time spent on social media platforms and LinkedIn effectiveness, on the other, is stronger for passive candidates, demonstrating the important role of social media platforms for attracting passive candidates.

Regarding this, Chlebovský (2015) revealed in his surveys that the most popular social media platforms are Facebook and LinkedIn but very widely used are also Twitter and YouTube in the Czech Republic and in the Slovak Republic.

Pilař, Balcarová and Rojík (2016) present in their survey that Instagram is becoming increasingly popular as a marketing communication tool and should be actively and purposefully used in any area.

According to Kuchárová Mačkayová (2013), there is a relationship between the generation $\mathrm{Y}$ employees and modern information and communications technology - mobile phones and social media platforms. She found that most members of generation Y communicate through phone. Up to $93.1 \%$ of respondents use it for calling and sending SMS or MMS. They actively communicate their ideas, feelings and attitudes on social media platforms. Seven out of ten respondents visit social media platforms daily. Only $5.5 \%$ of respondents are not members of any social network.

Employee relationship management constitutes an emerging trend of managing human resource by building and maintaining individualized and mutually valuable relationships with employees based on online environment and information technology. However, given the early and still emerging state, there is little knowledge and agreement regarding employee relationship management (Strohmeier, 2013).

Biesok and Wyród-Wróbel (2017) occupied with the relation between job satisfaction and proactive behaviour of employees. Their studies clearly indicate the impact of job satisfaction on proactive attitude. This finding may be related to marketing communication tools such as the world of mouth marketing (buzz marketing). A satisfied employee actively presents his employer to his family, friends and acquaintances. This presentation can create the impression of a good and successful employer on the labor market and the desire of people to work for this employer.

\section{CONCLUSION}

The aim of this paper was to determine the current state of the use of social media platforms based on (1) the biological age of the respondents and (2) the highest level of education achieved of the respondents in selected corporations in the Czech Republic in the context of HR marketing. The results came along with the finding that there is a statistically significant relation between the active use of social media platforms and the biological age of the respondents, and there is a statistically significant relation between the active use of social media platforms and the highest level of education achieved of the respondents in selected corporations in the Czech Republic. 
It was also investigated where addressed respondents received information about a job vacancy. The most frequent information channel has become Internet job portals (and/or email messages). Among other things, this finding supports the development of the online environment and the digitization process in the field of human resource management.

Therefore, it is important to be able to choose the right promotional and marketing tools for communication with both candidates and current employees. The HR department of each corporation should today be able to connect traditional tools of personnel communication with new tools, to exploit the opportunities and benefits of social media platforms, and the development of online environments and digitization.

In this context, the whole process of HR marketing plays its irreplaceable role and importance because corporations grow, expand, and the amount of talented employees is insufficient.

Originality and a newness of this research paper are based on the finding of the current state of the use of social media platforms by respondents (employees) in selected corporations in the Czech Republic in the context of HR marketing.

The study is limited to respondents (1) from selected corporations and (2) from Czech Republic, which makes it difficult to generalise research discoveries to other countries. Another limitation of this study is a fact that the number of respondents was not so large. Nevertheless, this study offers original and interesting ideas and chances or opportunities for other research studies.

In the future research, (1) the research topic can be extended to other countries, for example the Slovak Republic or other V4 countries, (2) the structure of the addressed employees working in corporations can be more diverse, (3) other factors or variables can be investigated in connection with HR marketing in corporations.

\section{REFERENCES}

ALLEN, D. G., MAHTO, R. V. and OTONDO, R. F. 2007. Web-based recruitment: effects of information, organizational brand, and attitudes toward a Web site on applicant attraction. Journal of Applied Psychology, 92(06): 1696-1708.

ANDERSON, N. 2003. Applicant and Recruiter Reactions to New Technology in Selection: A Critical Review and Agenda for Future Research. International Journal of Selection and Assessment, 11(02/03): 121-136.

ANTOŠOVÁ, M. 2005. Marketing-mix v personalistice. Moderní rízení, 40(11): 42-44.

ARJOMANDY, D. 2016. Social media integration in electronic human resource management: Development of a social eHRM framework. Canadian Journal of Administrative Sciences, 33(02): 108-123.

BANNIKOVA, L. and KUCHKILDINA, M. 2013. Marketing of human resources is as HR strategy. In: Proceedings of the conference - 7th International Days of Statistics and Economics. Prague, Czech Republic, 19-21 September, pp. 61-69.

BENGTSSON, C. and BLOOM, M. 2017. Human Resource Management in a Digital Era. A qualitative study of HR managers' perceptions of digitalization and its implications for HRM. In partial fulfillment of the requirements for the degree of Master of Science in Business Administration. Lund University. Available at: http://lup.lub.lu.se/ luur/download?func=downloadFile\&recordOId=8914716\&fileOId=8914717 [Accessed: 2018, July 15].

BERLET, T. 2015. Personalmarketing in der Anästhesiologie. Wahrnehmung, Nutzung und Bewertung durch die Zielgruppe. Der Anaesthesist, 64(09): 659-668.

BIESOK, G. and WYRÓD-WRÓBEL, J. 2017. Job Satisfaction and Its Influence on Proactive Behaviour. European Journal of Business Science and Technology, 03(01): 44-53.

BONDAROUK, T. and RUËL, H. 2009. Electronic Human Resource Management: Challenges in the digital era. The International Journal of Human Resource Management, 20(03): 505-514.

BÖHM, S. and NIKLAS, S. J. 2012. Mobile recruiting: insights from a survey among german HR managers. In: Proceedings of the 50th annual conference on Computers and People Research - SIGMIS-CPR'12. Milwaukee, Wisconsin, USA. May 31 - June 02, pp. 117-122.

BREDIN, K. and SÖDERLUND, J. 2011. Human Resource Management in Project-Based Organizations: The HR quadriad framework. $1^{\text {st }}$ Edition. United Kingdom: Palgrave Macmillan.

BRICE, T. S. and WAUNG, M. 2002. Web site recruitment characteristics: America's best versus America biggest. S.A.M. Advanced Management Journal, 67(02): 04-08.

CARPENTIER, M., VAN HOYE, G., STOCKMAN, S., SCHOLLAERT, E., VAN THEEMSCHE, B. and JACOBS, G. 2017. Recruiting nurses through social media: Effects on employer brand and attractiveness. Journal of Advanced Nursing, 73(11): 2696-2708.

COCULOVÁ, J. 2015. An Analysis of Determinants of Recruitment and Selection Outsourcing Implementation. Acta Universitatis Agriculturae et Silviculturae Mendelianae Brunensis, 63(01): 185-191.

DABIRIAN, A., KIETZMANN, J. and DIBA, H. 2017. A great place to work!? Understanding crowdsourced employer branding, Business Horizons, 60(01): 197-205.

DINEEN, B. R. and ALLEN, D. G. 2013. Internet recruiting 2.0: Shifting paradigms. In: CABLE, D. M. and YU, K. Y. T. (Eds.). The oxford handbook of recruitment. New York: Oxford University Press. 
EGEROVÁ, D. and EGER, L. 2017. Recruitment Through the Use of Corporate Websites - A Comparative Study. In: Education Excellence and Innovation Management through Vision 2020. Norristown: International Business Information Management Association, pp. 1137-1149.

GALOVSKÁ, M. 2017. Trends in the concept of personnel management and human resource management [in Czech: Trendy v koncepci personálního managementu a řízení lidských zdrojů]. In: Proceedings of the 12th Annual International Scientific Conference - New trends 2017: New Trends in Economics, Management, Marketing and Public Administration. Private College of Economic Studies Znojmo, 09-10 November, pp. 129-136.

GOGOLOVÁ, M., PONIŠČIAKOVÁ, O. and IVANKOVÁ, K. 2015. The Use of External Personnel Marketing in Slovakia. In: Procedia Economics and Finance, $4^{\text {th }}$ World Conference on Business, Economics and Management, WCBEM. Procedia Economics and Finance Volume 26. Elsevier Procedia, pp. 131-138.

CHAPMAN, D. S. and WEBSTER, J. 2003. The Use of Technologies in the Recruiting, Screening, and Selection Processes for Job Candidates. International Journal of Selection and Assessment, 11(02/03): 113-120.

CHARBONNIER-VOIRIN, A., POUJOL, J. F. and VIGNOLLES, A. 2017. De la congruence de valeurs à la marque employeur: quelles conséquences pour l'identification et le bouche-à-oreille vis-à-vis de l'organisation? Canadian Journal of Administrative Sciences, 34(04): 17-26.

CHLEBOVSKÝ, V. 2015. Comparison of Czech, Slovak and Swiss Product Innovation Oriented Firms' Communication in Social Media. Acta Universitatis Agriculturae et Silviculturae Mendelianae Brunensis, 63(05): 1653-1659.

JÁNOŠOVÁ, D. 2016. Human resources and personnel marketing management in business practice from the perspective of globalization. In: Proceedings of the 16th International Scientific Conference on Globalization and its Socio-Economic Consequences. Rajecké Teplice, Slovakia. 05-06 October, pp. 767-774.

KLIMENTOVÁ, L. 2008. Personálny manažment verzus personálny marketing. In: Dny práva - Days of Law. Právnická fakulta Masarykovy univerzity, Brno, Czech Republic, pp. 137-149.

KUCHÁROVÁ MAČKAYOVÂ, V. 2013. Actuals Trends in the Process of Employees' Recruitment in the Context of the Modern Information and Communication Technologies. Trendy ekonomiky a managementu/Trends Economics and Management, 07(16): 65-75.

LAUMER, S., ECKHARDT, A. and WEITZEL, T. 2010. Electronic Human Resources Management in an E-Business Environment. Journal of Electronic Commerce Research, 11(04): 240-250.

LVOVNA, S. T. and VIKTOROVICH, V. S. 2017. Creating a competitive workplace in the modern world. The Turkish Online Journal of Design, Art and Communication TOJDAC, 7(Special Edition): 1196-1207.

MAURER, S. D. and LIU, Y. 2007. Developing effective e-recruiting websites: Insights for managers from marketers. Business Horizons, 50(04): 305-314.

MCFARLAND, L. A. and PLOYHART, R. E. 2015. Social media: A contextual framework to guide research and practice. Journal of Applied Psychology, 100(06): 1653-1677.

MELANTHIOU, Y., PAVLOU, F. and CONSTANTINOU, E. 2015. The Use of Social Network Sites as an E-Recruitment Tool. Journal of Transnational Management, 20(01): 31-49.

MOQBEL, M. and FUI-HOON NAH, F. 2017. Enterprise Social Media Use and Impact on Performance: The Role of Workplace Integration and Positive Emotions. Transactions on Human-Computer Interaction, 09(04): 261-280.

NADÁNYIOVÁ, M. 2016. Global trends of the personnel marketing in service enterprises. In: Proceedings of the 16th International Scientific Conference on Globalization and its Socio-Economic Consequences. Rajecké Teplice, Slovakia. 05-06 October, pp. 1474-1481.

NIKOLAOU, I. 2014. Social networking web sites in job search and employee recruitment. International Journal of Selection and Assessment, 22(02): 179-189.

PILAŘ, L., BALCAROVÁ, T. and ROJÍK, S. 2016. Farmers' Markets: Positive Feelings of Instagram Posts. Acta Universitatis Agriculturae et Silviculturae Mendelianae Brunensis, 64(06): 2095-2100.

PLUMMER, M., HILTZ, S. and PLOTNICK, L. 2011. Predicting Intentions to Apply for Jobs Using Social Networking Sites: An Exploratory Study. In: Proceedings of the 44th Hawaii International Conference on System Sciences - 2011. 04 - 07 January, 01 - 10. DOI: 10.1109/HICSS.2011.346.

ROTH, P. L., BOBKO, P., VAN IDDEKINGE, C. H. and THATCHER, J. B. 2016. Social media in employeeselection-related decisions: A research agenda for uncharted territory. Journal of Management, 42(01): 269-298.

RYAN, A. M. and WESSEL, J. L. 2015. Implications of a changing workforce and workplace for justice perceptions and expectations. Human Resource Management Review, 25(01): 162-175.

SHENG, H., FUI-HOON NAH, F. and SIAU, K. 2005. Strategic Implications of Mobile Technology: A Case Study Using Value-Focused Thinking. Journal of Strategic Information Systems, 14(01): 269-290.

STONE, D. L. and DEADRICK, D. L. 2015. Challenges and opportunities affecting the future of human resource management. Human Resource Management Review, 25(01): 139-145.

STONE, D. L. and DULEBOHN, J. H. 2013. Emerging issues in theory and research on electronic human resource management (eHRM). Human Resource Management Review, 23(01): 01-05.

STRENITZEROVÁ, M. 2016. HR marketing in terms of HR managers and employees - application e-marketing tools. In: Proceedings of the International Scientific Conference on Marketing Identity 2016: Brands We Love. Slovak Acad Sci., Smolenice, 08 - 09 November, pp. 463-473. 
STROHMEIER, S. 2013. Employee relationship management - Realizing competitive advantage through information technology? Human Resource Management Review, 23(01): 93-104.

SZOZDA, N. 2011. Instrumenty marketingu wewnętrznego w firmach usługowych branży IT. Zeszyty Naukowe Wyższej Szkoły Zarzadzania Ochrona Pracy w Katowicach, 01(07): 173-185.

THOMAS, S. L. and RAY, K. 2000. Recruiting and the Web: High-Tech Hiring. Business Horizons, 43(02): 43-52.

UNGERMAN, O. 2016. Use of Social Networks in Personnel Marketing. In: Proceedings of the International Scientific Conference of Business Economics Management and Marketing (ISCOBEMM). Brno, Czech Republic. 15-16 September, pp. 83-92.

UNGERMAN, O. and MYSLIVCOVÁ, S. 2016. Personnel marketing in the Czech economy: past and present. ACC Journal, 22(02): 28-43.

URBANCOVÁ, H. and HUDÁKOVÁ, H. 2017. Benefits of Employer Brand and the Supporting Trends. Economics and Sociology, 10(04): 41-50.

URBANCOVÁ, H., STACHOVÁ, K. and STACHO, Z. 2015. Methods of Recruitment in the Czech and Slovak Organizations. Acta Universitatis Agriculturae et Silviculturde Mendelianae Brunensis, 63(03): 1051-1060.

VANNAN, M. and CHANDRA MOHAN, A. 2014. Proposing a model for user satisfaction in electronic Human resource management. International Journal of Applied Engineering Research, 09(20): 7579-7595.

VENTURA, M. 2013. Which is the best employer review site? (Glassdoor vs. The Contenders). UndercoverRecruiter. [Online]. Available at: http://theundercoverrecruiter.com/employer-reviews/ [Accessed: 2018, January 20].

WATSON, T. 2009. Organizations, Strategies and Human Resourcing. In Leopold, John W. and Harris, Lynette (eds.) (2009). The Strategic Managing of Human Resources, $2^{\text {nd }}$ Edition. Harlow: Prentice Hall/Financial Times. 